\title{
Proximate Composition, Phytoconstituents and Mineral Contents of Soybean (Glycine Max) Flour Grown and Processed in Northern Nigeria
}

\author{
Useh Mercy Uwem ${ }^{1, ~}$, Adebiyi Adedayo Babafemi ${ }^{1}$, Dauda Mary Sunday ${ }^{2}$ \\ ${ }^{1}$ Chemistry Advanced Research Centre, Sheda Science and Technology Complex, Kwali, Abuja, Nigeria \\ ${ }^{2}$ Chemistry Department, University of Abuja, Abuja, Nigeria
}

Email address:

usehmercy@gmail.com (U. M. Uwem)

${ }^{*}$ Corresponding author

\section{To cite this article:}

Useh Mercy Uwem, Adebiyi Adedayo Babafemi, Dauda Mary Sunday. Proximate Composition, Phytoconstituents and Mineral Contents of Soybean (Glycine Max) Flour Grown and Processed in Northern Nigeria. Advances in Applied Sciences. Vol. 2, No. 4, 2017, pp. 48-53. doi: $10.11648 /$ j.aas.20170204.12

Received: October 4, 2016; Accepted: January 13, 2017; Published: August 1, 2017

\begin{abstract}
Soybean (Glycine max), is a species of legume widely grown for its edible bean which has numerous uses. Soybeans are an important source of not only proteins, but carbohydrates, fats, and many essential vitamins and minerals. So, they facilitate normal growth and development in young children. In this study, the phytoconstituents, proximate composition and mineral contents of soybean flour was evaluated using standard processing techniques. The preliminary phytochemical screening indicated the presence of phenols, cardiac glycosides, steroids, saponins, flavonoids in both the methanol and aqueous extracts. The quantitative phytochemical screening showed that saponin had the highest content (18.4\%) followed by phenol (16.8\%) and flavonoids (12.4\%) while phytate was the least $(0.07 \%)$. The proximate composition was in this order: protein $>$ carbohydrate $>$ crude fat $>$ moisture $>$ crude fibre $>$ ash content which showed that the soy flour is relatively high in protein. The minerals analyzed for were: $\mathrm{Ca}$ (231.6), Fe (5.790), Mg (249.8), Zn (2.414) and Mn (0.651) which were within the FAO/WHO standards for metals in foods.
\end{abstract}

Keywords: Soybean, Phytoconstituents, Protein, Soy Flour, Saponin

\section{Introduction}

The soybean (Glycine max (L.) Merrill) belongs to the legume family, native to Eastern Asia and introduced into Nigeria in 1908. The main producers of soy are the United States (36\%), Brazil (36\%), Argentina (18\%), China (5\%) and India (4\%). [1]. Soybean is a leguminous vegetable of the pea family that grows in tropical, subtropical, and temperate climates. It has long been recognized as a plant food that, when compared with other plants, is relatively high in protein. The plant is classed as an oilseed rather than a pulse by the UN Food and Agriculture Organization (FAO). It is an important inexpensive food crop that contains about $40 \%$ protein, $30 \%$ carbohydrates, excellent amounts of dietary fiber, vitamins, minerals and $20 \%$ oil which makes it second only to groundnuts in terms of oil content amongst food legumes [2]. Many leguminous crops provide some protein, but soybean is the only available crop that provides an inexpensive and high quality source of protein comparable to meat, poultry and eggs [3]. Historically it is nick-named "meat of the field" or "meat without bones" because it is the only vegetable with a complete protein [4]. The gold standard for measuring protein quality is the Protein Digestibility Corrected Amino Acid Score (PDCAAS) and by this criterion soy protein is the nutritional equivalent of meat, eggs, and casein for human growth and health [5].

Over the years, soybean consumption has been a matter of much debate. But recently researchers have taken a very close look at the protein content of soybeans and arrived at many fascinating conclusions. Along with this increasing interest in soy protein came the discovery of very unique proteins, typically referred to as "peptides" which include defensins, glycinins, conglycinins and lunasin, and all are now known to provide us with health benefits in the areas of 
improved blood pressure regulation, better control of blood sugar levels, and improved immune function [6].

Soy protein has the ability to lower LDL (bad cholesterol) levels and decrease the risk of coronary heart disease (CHD). Even people suffering from diabetes can receive significant health benefits from consuming soybeans [7]. Oil obtained from soybeans is very rich in essential fatty acids like linoleic and linolenic acids. Both are very important for human health, as they help regulate blood pressure and facilitate the absorption of vital nutrients [8]. Soybean contains isoflavones that minimizes the risk of developing certain cancers, particularly, genistein - an isoflavone that has extensive antioxidant properties. It also serves as an excellent source of essential fatty acids, calcium, magnesium, lecithin, riboflavin, thiamin, fiber, folate (folic acid) and iron [9].

Soybean also improves soil fertility by adding nitrogen from the atmosphere. This is a major benefit in African farming systems, where soils have become exhausted by the need to produce more food for increasing populations, and where fertilizers are hardly available and are expensive for farmers [10].

Malnutrition, mostly protein deficiency, is prevalent in many parts of Africa as animal protein is too expensive for most populations. Children in most developing countries, particularly those in low-income classes, are weaned on cheap, readily available starchy foods such as pap in which soybean flour is mainly used to supplement this popular weaning and breakfast recipe [11].

The beans can be processed in a variety of ways. Common forms of soy include soy meal (the material remaining after solvent extraction of oil from soybean flakes, with a $50 \%$ soy protein content. The meal is 'toasted' and ground in a hammer mill. Soybean meal is an essential element of the American production method of growing farm animals, such as poultry and swine, and more recently the aquaculture of catfish); soy flour; soy milk; tofu; tempeh; miso; natto and soybean oil (a vegetable oil extracted from the seeds of the soybean) [12].

Soy flour is used as an ingredient in foods, beverages, and condiments to promote higher optimal health benefit. However, soy can cause some mild side effects such as bloating and nausea. It can also cause allergic reactions involving rash and itching in some people. There is concern that taking high doses might cause abnormal tissue growth in the uterus. So while soy in moderation can be beneficial to your health, too much of it may cause a few health problems. But alongside of the many controversies swirling around soybeans and health, it's important not to lose sight of the strong nutritional value of this legume [13].

Soybean seed, like other legumes, is known to contain significant amounts of all the essential amino acids, minerals, phytate and oxalates but these anti-nutritional factors are usually removed or greatly reduced by soaking, fermentation and hydrothermal treatment during processing [14]. In recent times, concerns over the possible make-up of this wonderful legume due to its numerous health benefits made this research work absolutely imperative.

\section{Materials and Methods}

\subsection{Sample Collection and Preparation}

The soybean (Glycine max (L.) Merrill) seeds used for this work were purchased from Kubwa market in Bwari Area Council, Abuja, Nigeria. It was transferred to the laboratory, sieved to remove stones and debris, washed and soaked for 48 hours, oven dried at $40^{\circ} \mathrm{C}$ for 5 minutesand dehulled with the aid of hammer mill. The dehulled beans was ground finely enough with the use of a specialized Alpine Fine Impact Mill, model A90BD to pass through a $0.25 \mathrm{~mm}$ screen [15]. The so made soy flour was packaged in moisture-proof, air-tight polyethylene containers and kept at $4{ }^{\circ} \mathrm{C}$ prior to analyses.

\subsection{Methanol Extract}

The methanol extract of the soybean flour was prepared by soaking $20 \mathrm{~g}$ of the sample in $200 \mathrm{ml}$ of methanol for 12 hours. The extract was then filtered through a funnel lined with Whatman No. 42 filter paper. The filtrate was concentrated and stored in an airtight container.

\subsection{Aqueous Extract}

The aqueous extract of the soybean flour was prepared by soaking $20 \mathrm{~g}$ of the sample in $400 \mathrm{ml}$ of distilled water for 12 hours. The extract was then filtered using filter paper, concentrated and stored in an airtight container.

\section{Qualitative Phytochemical Constituents}

A small portion of the filtrate was used for the qualitative phytochemical screening using standard methods [16, 17].

\subsection{Test for Tannins (Braymer's Test)}

$0.5 \mathrm{~g}$ of extract was stirred with $10 \mathrm{mls}$ of distilled water and then filtered. $2 \mathrm{ml}$ of the filtrate was treated with $1 \%$ alcoholic ferric chloride solution and observed for formation of blue-black or greenish colour solution.

\subsection{Test for Phenols (Ferric Chloride Test)}

The extract $(50 \mathrm{mg})$ was dissolved in $5 \mathrm{ml}$ of distilled water. To this few drops of neutral $5 \%$ ferric chloride solution was added. A dark green colour indicates the presence of phenolic compound.

\subsection{Test for Cardenolides}

$2 \mathrm{ml}$ of benzene was added to $1 \mathrm{ml}$ of the sample extract. The formation of a turbid brown colour indicated the presence of cardenolides.

\subsection{Test for Cardiac Glycosides (Keller Kelliani's Test)}

$5 \mathrm{ml}$ of each extract was treated with $2 \mathrm{ml}$ of glacial acetic acid in a test tube and a drop of ferric chloride solution was 
added to it. This was carefully underlayed with $1 \mathrm{ml}$ concentrated sulphuric acid. A brown ring formation at the interface indicated the presence of deoxysugar characteristics of cardiac glycosides.

\subsection{Test for Phlobatannins (Precipitate Test)}

Deposition of a red precipitate when $2 \mathrm{mls}$ of extract was boiled with $1 \mathrm{ml}$ of $1 \%$ aqueous hydrochloric acid was taken as evidence for the presence of phlobatannins.

\subsection{Test for Steroids (Libermann-Burchard Test)}

To $2 \mathrm{ml}$ of the test solution, a few drops of chloroform, 3 4 drops of acetic anhydride and one drop of concentrate sulphuric acid were added. Appearance of purple colour, which changes to blue or green colour, showed the presence of steroid.

\subsection{Test for Saponins (Foam Test)}

To $2 \mathrm{mls}$ of extract was added $6 \mathrm{ml}$ of water in a test tube. The mixture was shaken vigorously and observed for the formation of persistent foam that confirmed the presence of saponins.

\subsection{Test for Volatile Oil}

For volatile oil estimation $50 \mathrm{mg}$ of extract was taken and subjected to hydro-distillation. The distillate was collected in graduate tube of the assembly, wherein the aqueous portion automatically separated out from the volatile oil.

\subsection{Test for Flavonoids (Alkaline Reagent Test)}

$2 \mathrm{ml}$ of extracts was treated with few drops of $20 \%$ sodium hydroxide solution. Formation of intense yellow colour, which becomes colourless on addition of dilute hydrochloric acid, indicated the presence of flavonoids.

\subsection{Test for Carbohydrates (Molisch's Test)}

Few drops of Molisch's reagent were added to $2 \mathrm{ml}$ portion of the various extracts. This was followed by addition of $2 \mathrm{ml}$ of conc. $\mathrm{H}_{2} \mathrm{SO}_{4}$ down the side of the test tube. The mixture was then allowed to stand for two-three minutes. Formation of a red or dull violet colour at the interphase of the two layers was a positive test.

\section{Quantitative Phytochemical Constituents}

\subsection{Test for Phenol}

This was determined using spectrophotometric method. The sample was boiled with diethyl ether for 15 mins. $5 \mathrm{ml}$ of the boiled sample was then pipette into $50 \mathrm{ml}$ flask and 5 $\mathrm{ml}$ of distilled water was added. Then, $2 \mathrm{ml}$ of $\mathrm{NH}_{4} \mathrm{OH}$ solution and $5 \mathrm{ml}$ of conc. butanol was added to the mixture. The sample was made up to mark and left for 30 mins. to react for colour development. The absorbance was measured at $505 \mathrm{~nm}[18]$.

\subsection{Test for Saponin}

$0.5 \mathrm{~g}$ of the sample was added to $20 \mathrm{ml}$ of $1 \mathrm{~N} \mathrm{HCl}$ and was boiled for 4 hours. This was filtered after cooling and 50 $\mathrm{ml}$ of petroleum ether was added to the filtrate for ether layer and evaporated to dryness. $5 \mathrm{ml}$ of acetone-ethanol was added to the residue. $0.4 \mathrm{ml}$ each was taken into 3 different test tubes, $6 \mathrm{ml}$ of $\mathrm{FeSO}_{4}$ reagent was added into them followed by $2 \mathrm{ml}$ of concentrated $\mathrm{H}_{2} \mathrm{SO}_{4}$ acid. It was thoroughly mixed after 10 mins. and the absorbance was taken at $490 \mathrm{~nm}[19,20]$.

\subsection{Test for Flavonoid}

This was done by acid hydrolysis of spectrophotometric method. $0.5 \mathrm{~g}$ of the sample was mixed with $5 \mathrm{ml}$ of dilute $\mathrm{HCl}$ acid and boiled for 10 mins. the boiled extract was allowed to cool and then filtered. $1 \mathrm{ml}$ of the filtrate was added to $3 \mathrm{ml}$ of ethyl acetate and $5 \mathrm{ml}$ of $1 \% \mathrm{NH}_{3}$. This was then scanned from $420-520 \mathrm{~nm}$ for the absorbance [21].

\subsection{Taste for Phytate}

This was determined by the photometric method of Latta and Esin [22]. $2 \mathrm{~g}$ of the test sample was extracted with 100 $\mathrm{ml}$ of $2.4 \% \mathrm{HCl}$ acid by shaking vigorously in a vortex mixer for 1 hour and then filtered through Whatman No. 5 filter paper. $5 \mathrm{ml}$ of the filtrate was mixed with $1 \mathrm{ml}$ of $0.1 \mathrm{M} \mathrm{Na}$ EDTA, $0.75 \mathrm{M} \mathrm{NaOH}$ solution and then made up to $25 \mathrm{ml}$ with distilled water before being placed on an ion-exchange (AGIX4, 100-200mesh) column. The column was washed with $15 \mathrm{ml}$ of distilled water and then $15 \mathrm{ml}$ of $0.1 \mathrm{~m} \mathrm{NaCl}$ before being eluted with $15 \mathrm{ml}$ of $0.7 \mathrm{M} \mathrm{NaCl}$. The eluate was collected and wet digested in a Kjeldahl apparatus with $0.5 \mathrm{ml}$ conc. $\mathrm{H}_{2} \mathrm{SO}_{4}$ and $3 \mathrm{ml} \mathrm{HCl}$. The digest was cooled to room temperature, $10 \mathrm{ml}$ of distilled water added and the mixture heated again on a water bath with $2 \mathrm{ml}$ of $2.5 \%$ ammonium molybdate solution in $1 \mathrm{~N} \mathrm{H}_{2} \mathrm{SO}_{4}, 1 \mathrm{ml}$ conc. $\mathrm{H}_{2} \mathrm{SO}_{4}$ and then made up to $50 \mathrm{ml}$ in a volumetric flask. The solution was allowed to stand for 15 mins before taking the absorbance at $640 \mathrm{~nm}$ against a blank. This was done in triplicate [23].

\subsection{Test for Oxalate}

Deionized water was heated at $29^{\circ} \mathrm{C}$ and the sample was soaked for 1 minute. $1 \mathrm{ml}$ of $5 \mathrm{M} \mathrm{NaOH}, 1 \mathrm{ml}$ of $5 \% \mathrm{CaCl}_{2}$ and 3 drops of phenolphthalein was added to $5 \mathrm{ml}$ of extract and allowed to stand for 3 hours. This was centrifuged at 300 rpm for 15 mins. The supernatant was discarded and the precipitate was washed with hot water and allowed to centrifuge. $2 \mathrm{ml}$ of $3 \mathrm{M} \mathrm{H}_{2} \mathrm{SO}_{4}$ was pipette into it and transferred into a conical flask. The precipitate was dissolved by warming in a water bath at $80^{\circ} \mathrm{C}$. The content of each tube was then titrated with freshly prepared $0.01 \mathrm{M} \mathrm{KMnO}_{4}$. The titration was carried out at ordinary temperature until a first colour change was observed. It was allowed to stand until the changed to colourless. The solution was warmed at $70^{\circ} \mathrm{C}$ and 
titration was carried out until a pink colour persists at least for 30 seconds [24].

\section{Proximate Composition}

The proximate analysis (moisture, ash, crude protein, crude fibre, crude fat and carbohydrate) of the sample was determined using the standard method of AOAC [25]. All determinations were done in triplicate and reported in percentage.

Table 1. Qualitative analysis of phytochemical constituents of soy flour.

\begin{tabular}{lll}
\hline Phytochemical parameters & Methanol extract & Aqueous extract \\
\hline Tannins & - & - \\
Phenols & + & + \\
Cardenolides & - & - \\
Cardiac glycosides & + & + \\
Phlobatannins & - & - \\
Steroids & + & + \\
Saponins & + & + \\
Volatile oils & - & - \\
Flavonoids & + & + \\
Carbohydrates & - & + \\
\hline
\end{tabular}

Key: $(+)=$ present, $(-)=$ absent

Table 2. Quantitative analysis of phytochemical constituents.

\begin{tabular}{ll}
\hline Variables & Percentage (\%) \\
\hline Phenols & 16.8 \\
Saponins & 18.4 \\
Flavonoids & 12.4 \\
Phytates & 0.07 \\
Oxalates & 0.15 \\
\hline
\end{tabular}

Table 3. Proximate Composition of Soybean flour.

\begin{tabular}{ll}
\hline Parameters & Values $\mathbf{( \% )}(\mathbf{n}=\mathbf{3})$ \\
\hline Moisture & 6.84 \\
Ash & 4.92 \\
Crude Protein & 35.6 \\
Crude Fibre & 6.27 \\
Crude Fat & 18.5 \\
Carbohydrate & 27.87 \\
\hline
\end{tabular}

Table 4. Mineral contents of Soybean flour $(\mathrm{mg} / \mathrm{kg})$.

\begin{tabular}{lll}
\hline Parameters & Values & FAO/WHO guidelines \\
\hline $\mathrm{Ca}$ & 231.6 & - \\
$\mathrm{Fe}$ & 5.790 & 48 \\
$\mathrm{Mg}$ & 249.8 & 300 \\
$\mathrm{Zn}$ & 2.414 & 60 \\
$\mathrm{Mn}$ & 0.651 & 1.0 \\
\hline
\end{tabular}

\section{Results and Discussion}

The results of the phytoconstituents of Glycine $\max (L$.) Merrill as determined are recorded in tables 1 and 2 while the proximate compositions and the mineral contents are presented in tables 3 and 4 . Of the fifteen phytochemicals screened for, five were found present in two solvent extracts. The preliminary phytochemical screening indicated the presence of phenols, cardiac glycosides, steroids, saponins, flavonoids in both the methanol and aqueous extracts. In addition, the aqueous extract also showed the presence of carbohydrate while it was absence in the methanol extract. From the active compounds indicated, it is obvious that Glycine $\max ($ L.) Merrill is a potential source of useful drugs. From table 2, saponin had the highest percentage content (18.4\%) followed by phenol (16.8\%) and flavonoids (12.4\%) while phytate was the least $(0.07 \%)$.

Saponins are a class of chemical compounds found in particular abundance in various plant species. More specifically, they are amphipathic glycosides grouped phenomenologically by the soap-like foaming they produce when shaken in aqueous solutions, and structurally by having one or more hydrophilic glycoside moieties combined with a lipophilictriterpene derivative [26]. In other words, saponins are sterols that are present naturally in a wide variety of foodplants, including vegetables, legumes and cereals. Legumes such as soybean and chickpeas are the major source of saponins in form of soyasaponins (group A and group B) and soyasapogenols in the human diet [27]. Soybeans also contain the isoflavones genistein and daidzein, types of phytoestrogen which are closely related to the antioxidant flavonoids. Genistein is a soy component that could easily be singled out for its antioxidant properties! Increased activity of antioxidant enzymes - including superoxide dismutase, glutathione peroxidase, catalase, and glutathione reductasehas now been linked to intake of genistein from soy [28]. Another group of antioxidant phytonutrients called phenolic acids has also been recently investigated in soybeans. When we enjoy this antioxidant-rich legume, we also benefit from its phenolic acids, including caffeic, coumaric, ferulic, and sinapic acid. Phytic acid in soybeans has many effects including acting as an antioxidant and a chelating agent. It helps in reducing cancer, minimizing diabetes and reducing inflammation. However, phytic acid is also criticized for reducing vital minerals due to its chelating effect, but this effect is greatly reduced during processing [29].

From table 3, crude protein had the highest value $(35.6 \%)$ while moisture content $(4.84 \%)$ was the lowest which showed hindrance to microorganism growth. Most soy protein is a relatively heat-stable storage protein. This heat stability enables soy food products requiring high temperature cooking to be made. Soybeans are considered by many agencies to be a source of complete protein. For this reason, soy is a good source of protein, amongst many others, for people who want to reduce the amount of meat they eat. According to the US Food and Drug Administration, soy protein products can replace animal-based foods - which also have complete proteins but tend to contain more fat, especially saturated fat-without requiring major adjustments elsewhere in the diet. Even soy-based infant formula (SBIF) is sometimes given to infants who are not being strictly breastfed because of its richness in protein; it can be useful for infants who are either allergic to pasteurized cow milk proteins or who are being fed a vegan diet. Diverse studies have concluded there are no adverse effects in human growth, development, or reproduction as a result of the consumption of soy-based infant formula. SBIFs provide 
complete nutrition that adequately supports normal infant growth and development. FDA has accepted SBIFs as safe for use as a good source of nutrition [30].

From table 4, the minerals analyzed for were: Ca (231.6), $\mathrm{Fe}$ (5.790), Mg (249.8), Zn (2.414) and Mn (0.651) which were within the $\mathrm{FAO} / \mathrm{WHO}$ standards for metals in foods [31]. Ca is needed in the body for healthy bones and teeth; helps muscles relax and contract; important in nerve functioning, blood clotting, blood pressure regulation, immune system health. Fe is important because it is part of a molecule (hemoglobin) found in red blood cells that carries oxygen in the body; needed for energy metabolism. $\mathrm{Mg}$ also is found in bones; needed for making protein, muscle contraction, nerve transmission, immune system health. $\mathrm{Zn}$ is part of many enzymes; needed for making protein and genetic material; has a function in taste perception, wound healing, normal fetal development, production of sperm, normal growth and sexual maturation, immune system health. Since legumes like soybeans are often overshadowed by vegetables and fruits in terms of nutrient richness, we sometimes forget just how beneficial legumes like soybeans can be. Along with the nutrients listed above, soybeans are also an important source of the minerals copper, manganese, molybdenum, phosphorus, and potassium; the B vitamin, riboflavin; and omega-3 fatty acids (in the form of alphalinolenic acid). Soybean oil has an omega-3: omega- 6 ratio of $1: 7$ [32]. This is a significantly higher omega- 3 content than in other vegetable cooking oils. In addition to all of the nutrient richness described above, soybeans also offer many unique nutrients less familiar to most people. The health benefits of these nutrients are only beginning to be understood by researchers.

\section{Conclusion}

Soybeans are perhaps best known for their fantastic blend of protein and fiber. They are a very good source of manganese, phosphorus, and protein as well as a good source of iron, omega-3 fatty acids, dietary fiber, magnesium, and vitamin $\mathrm{K}$. There are also a wide range of unique proteins, peptides, and phytonutrients contained in soy which include flavonoids, isoflavonoids, phenolic acids and saponins (soyasaponins from group A and group B, and soyasapogenols) which are very useful for optimal health. Soy is used for high cholesterol, high blood pressure, and preventing diseases of the heart and blood vessels. It is also used for type 2 diabetes, asthma, lung cancer, endometrial cancer, prostate cancer, and thyroid cancer, as well as preventing weak bones (osteoporosis), and slowing the progression of kidney disease. In foods, soy is used as a milk substitute in infant feeding formulas, and as an alternative to cow's milk. Soybeans are eaten boiled or roasted. Soy flour is used as an ingredient in foods, beverages, and condiments. Other food sources contain these nutrients, but soybean is readily available and affordable. We recommend that persons wanting to use soy in treatment of any ailment need to pay attention to the form of the soy, the amount consumed, their personal health history, and in some cases, the advice of their healthcare provider.

\section{Acknowledgment}

The authors wish to acknowledge the management of Sheda Science and Technology Complex (SHESTCO) for their assistance.

\section{References}

[1] Shurtleff, William; Aoyagi, Akiko. 2013. History of Whole Dry Soybeans, Used as Beans, or Ground, Mashed or Flaked. Lafayette, California. 950 pp.

[2] UN Food and Agriculture Organization (FAO). (2007). Oilseeds. Washington D. C.

[3] Riaz, Mian N. (2006). Soy Applications in Food. Boca Raton, FL: CRC Press.

[4] Messina M. G. and Messina V. M. (2010). The Role of Soy in Vegetarian Diets Nutrients. Vol: 2 Issue: 8, pages 855-888.

[5] Friedman M, Brandon DL (2001) Nutritional and health benefits of soy proteins. J Agric. Food Chem 49: 1069-1086.

[6] Natarajan SS, Luthria D, Bae H, Lakshman D, Mitra A (2013) Transgenic soybean and soybean protein analysis: An overview. J Agric Food Chem 61: 11736-11743.

[7] Jenkins D. J, Jones P. J, Lamarche B. (2011). Effect of a dietary portfolio of cholesterol-lowering foods given at 2 levels of intensity of dietary advice on serum lipids in hyperlipidemia: a randomized controlled trial. JAMA. 306 (8): 831-9.

[8] Yimit D. F, Hoxur P. U, Amat N. I. (2011). Effects of soybean peptide on immune function, brain function, and neurochemistry in healthy volunteers. Nutrition. 4 (2): 72 82 .

[9] Barnes S. U. (2010). The Biochemistry, Chemistry and Physiology of the Isoflavones in Soybeans and their Food Products. Lymphat Res Biol. 8 (1): 89—98.

[10] Moller N. P, Scholz-aherns K. E, Roos N. E. (2008). Bioactive peptides and proteins from foods: indication for health effects. European Journal of Nutrition. 47 (4): 171-82.

[11] Merritt, Russell J.; Jenks, Belinda H. (2014). "Safety of SoyBased Infant Formulas Containing Isoflavones: The Clinical Evidence". The Journal of Nutrition (The American Society for Nutritional Sciences) 134 (5):

[12] Wikipedia, the free Encyclopedia. SoybeanOnline. Retrieved February 18, 2016.

[13] Strom, B. L.; Schinnar, R; Ziegler, EE; Barnhart, KT; Sammel, MD; MacOnes, GA; Stallings, VA; Drulis, JM; et al. (2011). "Exposure to Soy-Based Formula in Infancy and Endocrinological and Reproductive Outcomes in Young Adulthood". JAMA: the Journal of the American Medical Association (American Medical Association) 286 (7): 807-814.

[14] Anderson J. W. and Bush H. M. (2011). Soy protein effects on serum lipoproteins: a quality assessment and meta-analysis of randomized, controlled studies. J Am Coll Nutr. 30 (2): 79-91. 
[15] Amadou I. O., Yong-Hui S. J., Sun J. F and Davis M. K. (2009). Fermented Soybean Products: Some Methods, Antioxidants Compound Extraction and their Scavenging Activity. Asian Journal of Biochemistry. Vol: 4 Issue: 3 Pages/record No.: 68-76. 2009.

[16] Harbone J. B. (2010). Phytochemical Methods. Chapman and Hall Ltd. London.

[17] Chai C. B, Jul H. K, Kim S. C. (2011). Determination of bioactive compounds in fermented soybean products using GC/MS and further investigation of correlation of their bioactivities. Chromatogr B Analyt Technol Biomed Life Sci. Pharmacol Rep. 63 (3): 643-59.

[18] Michelfelder A. G. (2009) Soy: A Complete Source of Protein. American Family Physician 79. 1: 43-7.

[19] Klein M. A, Nahin R. L, Messina M. J. (2010). Guidance from an NIH Workshop on Designing, Implementing, and Reporting Clinical Studies of Soy Interventions. The Journal of Nutrition 140 (6): 119 -124.

[20] Oseni, T; Patel, R; Pyle, J; Jordan, VC (2008). "Selective Estrogen Receptor Modulators and Phytoestrogens.". Planta Med 74 (13): Soybeans: Chemistry, Technology, and Utilization. Berlin: Springer. p. 532.

[21] Lammersfeld C. A, King J. U, Walker S. (2009). Prevalence, sources, and predictors of soy consumption in breast cancer. Nutr J. 8: 2. Published online 2009 January 22. doi: 10.1186/1475-2891-8-2. 2009

[22] Butler L. M, Wu A. H, Wang R. G. (2010). A vegetable-fruitsoy dietary pattern protects against breast cancer among postmenopausal Singapore Chinese women. Am J Clin Nutr. 91 (4): 1013-1019.

[23] Merritt J. C. Metabolic syndrome: soybean foods and serum lipids. J Natl Med Assoc. 96 (8): 1032-1041.
[24] Gomes LS, Senna R, Sandim V, Silva-Neto MA, Perales JE, et al. (2014) Four conventional soybean [Glycine max (L.) Merrill] seeds exhibit different protein profiles as revealed by proteomic analysis. J Agric Food Chem 62: 1283-1293.

[25] Association of Official Analytical Chemists (AOAC). (2009). Official Methods of Analysis. Horwitz. $18^{\text {th }}$ ed.

[26] Messina M, Barnes S (2009) The role of soy products in reducing risk of cancer. J Natl Cancer Inst 83: 541-546.

[27] George Mateljan. (2015). The World's Healthiest Foods. George Mateljan Foundation. $2^{\text {nd }}$ ed.

[28] Ajay G. Y. and Arvind B. N. (2009) Genistein: A multipurpose isoflavone. International Journal of Green Pharmacy. Vol: 3 Issue: 3 Pages/record No.: 176-183. 2009.

[29] Committee on Food Protection, Food and Nutrition Board, National Research Council (2009). "Phytates". Toxicants Occurring Naturally in Foods. Washington, DC: National Academy of Sciences. pp. 363-371.

[30] Giampietro, P. G.; Bruno, G.; Furcolo, G.; Casati, A.; Brunetti, E.; Spadoni, G. L.; Galli, E. (2004). "Soy Protein Formulas in Children: No Hormonal Effects in Long- term Feeding". Journal of Pediatric Endocrinology and Metabolism (Freund Publishing House) 17 (2): 191- 196.

[31] Protein Quality Evaluation: Report of the Joint FAO/WHO Expert Consultation. (2009) Bethesda, MD (USA): Food and Agriculture Organization of the United Nations (Food and Nutrition Paper No. 51).

[32] Lanou A. J. Soy foods: are they useful for optimal bone health? Therapeutic Advances in Musculoskeletal Disease vol. 3 no. 6 293-300. 